International Journal of Business and Management 2 (4): 09-13, 2018

e-ISSN: 2590-3721

(C) RMP Publications, 2018

DOI: $10.26666 / \mathrm{rmp} . \mathrm{ijbm} .2018 .4 .2$

\title{
Public Private Partnership (PPP) in Malaysia
}

\author{
Mahirah bt Rafie, Saiful bin Mohamed Shuib \\ Jabatan Pelancongan dan Hospitaliti, Politeknik Tuanku Syed Sirajuddin, 02600 Arau, Perlis
}

\begin{abstract}
Public Private Partnership (PPP) is not a new method of development in a country. In Malaysia, concept of PPP had been used almost four decades after Malaysian Incorporated Policy had been introduced by the government. The objectives of this present study is to scrutinize defining the concept of PPP, the evolution of implementation PPP, and also characteristic and criteria of PPP based on Public Private Partnership Guidelines. This paper also examines the potential benefits of PPP implementation in Malaysia based on the previous study. Last but not least, issues and recommendation for future study has been suggested to enhance PPP implementation project.
\end{abstract}

Key words: Public Private Partnership, Privatization, Benefit and Risk, PPP Implementation, Economy, Evolution of Public Private Partnership

\section{INTRODUCTION}

Public Private Partnership or known as PPP is an innovative approach between government and public sector on collaborating and delivering goods, services and facilities in country. PPP has been adopted not only in Malaysia but also worldwide. PPP is popular choices for policymakers in order to develop country[1]. Partnership between government education institution and private education bodies can help system more efficient, flexible and effective [2].

This paper aims to shed light a review on the Malaysian PPP and highlights how the system has evolved over time. The review is conducted through extensive literature reviews of relevant documents and publications. The paper is structured into the following sections such as Section 1 introduction to the paper. Sections 2 present a brief overview of the Malaysian PPP, and Section 3 discusses the criteria of PPP projects. Thereafter, Section 4 highlights benefits of PPP implementation and Section 5 briefly discuss the issues arrived from PPP implementation and its recommendations. Subsequently, Section 6 provides the paper's concluding remarks

\section{OVERVIEW OF MALAYSIAN PPP}

\section{Evolution of PPP in Malaysia}

The ideology of partnership between public and private sector arise when the government introduced The Malaysian Incorporated Policy in 1981. This policy encourages cooperation both sectors within Malaysian company. The reason behind the existed was because of to reduce the financial and administrative burden of the government, improve skills and production, accelerate economic growth, reduce the size and involvement of public sector in the economic and to assist in reacting the country's economic policy goals [3].

After that in years 1983, the Privatization Policy also had been introduced by government to encourage to encourage private sectors' role towards economic growth in Malaysia. Government had detailed out the privatization policies, methods and implementations by introduced he Guidelines on Privatization in 1985. In 1991, government introduced the Privatization Master Plan to explain the policy and strategy of privatization. Since 1983, 510 partnership project between government and private sector already established especially in transportation, road, communications, health and energy.

Under the Ninth Malaysia plan in year 2006, The PPP officially announced in Malaysia and the main objective

Corresponding Author: Mahirah bt Rafie, Jabatan Pelancongan dan Hospitaliti, Politeknik Tuanku Syed Sirajuddin, 02600 Arau, Perlis, mahirah_rafie@yahoo.com, +60195752107 
was to further enhance private sector participation in economic development. Malaysian PPP basically has two main approach that called Privatization and Private Finance Initiative (PFI) which are similar but not the same [4]. Privatization was defined as a public sector that transfer activities and function to the private sector which is all the activities and functions before this were traditionally rested at the public sector [5]. While for the PFI, it defined as public sector took the responsible for finance and manage a package of capital investment and the services of public sector assets by transfer [6]. This capital investment and services were included the construction, management, maintenance, refurbishment and replacement of public sector asset that creates a standalone business.

There are two formats of PFI schemes in Malaysia [7]. The first format is private sector would construct the assets and lease it to government for specified fixed period of time while the second formats is it requires private sector to identify project that are deemed to be economically viable and give benefits towards public to be executed via PPP schemes. During the first format projects implementation, government formed and owned the Special Purpose Vehicle (SPV) or Syarikat Pembinaan PFI $S d n B h d$, which is wholly owned subsidiary of Ministry of Finance, got the responsibility to implements 425 projects that worth RM 20 billion which identified by the government under Ninth Malaysia Plan [8]. Funding from the Employees Provident Fund (EPF) will be channeled to a SPV [7].

Government had announcing allocation amounted 62.7 billion under Tenth Malaysia Plan to accomplished 52 PPP project such as plans to build seven toll highways, five Universiti Teknologi MARA branch campuses, the Integrated Transport Terminal in Gombak, privatization of Penang Port and redevelopment of Angkasapuri Complex, Kuala Lumpur as Media City. In year 2010 also, RM20 billion was allocated under Facilitation Fund for delivering to public sector in order to focus on development of certain project especially in infrastructure, health, tourism and education project development [9].

During the first implementation of PPP in Malaysia, government introduced four key's policies and strategies that related to the implementation of Privatization. All this four key's policies and strategies were introduced back in order to foster the involvement of private sectors in PPP projects [10].

Malaysian government through Public Private Partnership Unit, Prime Minister Department has published Public Private Partnership Guidelines in 2009 [11]. The guidelines focus on principles, characteristic and criteria of PPP project.

\section{CHARACTERISTIC OF PPP PROJECT}

Some of the key features or characteristics of PPP projects are as follows [11]:

- Relationship between public and private sectors is based on partnership

- Public sector procures specified outputs or outcomes of a service for a concession period

- Private sector determines the required inputs to achieve the specified output and the private sector is given latitude to introduce innovation into their designs and development to reduce overall costs

- Payment for services is based on predetermined standards and performance

- Promotes 'maintenance culture' where the concessionaires will be responsible for the long term maintenance of the assets throughout the operational tenure agreed upon;

- Integration of design, construction, finance, maintenance and operation - total package

- Transfer of assets at the end of the concession period becomes an option to the Government

- Optimal sharing of risks whereby risk is allocated to the party who is best able to manage it; and

- Whole Life Cycle Costing ('WLCC') whereby PPP projects are usually awarded based on lowest total cost over the concession period compared to lowest construction costs under the traditional procurement method -a paradigm shifts in the form of procurement objectives

\section{CRITERIA OF PPP PROJECT}

Before developing any PPP project, Public Private Partnership Unit, Prime Minister's Department will analyses the project using general criteria. Each propose project should meet the following criteria [3].

1. Output specification can be clearly identified and quantified

Public-private partnership project usually involves large amount of money and each sector intends to gain profits from this project. Identification of model used must be clearly recognize. Most of the project will used 3 main output specifications which is contracting, operating and transferring.

For certain government project may involve design and build by the private sector but financed by government. It is because government wants to transfer the design and 
construction risk to the private sector. Other than, the project is completed by schedule. But, the project may increase operational risk if any conflict between planning and environmental considerations involve. It also may affect the project costing. Model involve using this output are Build-Own-Operate (BOO), BuildDevelop-Operate (BDO) and DesignConstruct-Manage-Finance (DCMF).

Some project such as water and waste project, government will make a contract with public sector contractor to design, build and operate a public infrastructure and after certain period, it will be hand over back to the government. The government financed this project in intention to transfer of operating, design and construction risk from government to private sector. It also promotes private sector innovation and improve quality of operation, maintenance and value for money. The contracts can be holistic. Government also is able to focus on core public sector responsibilities. Tendering and contracts for this project are more complex because the contract management must have monitored the performance by schedule. If any unsatisfactory about the project will back to the government. Model used this output specification are BuyBuild Operate (BBO), Lease-Develop-Operate (LDO), and Wrap-Around-Addiction (WAA).

Last but not least, any project which need a private sector to design, build, operate and finance an infrastructure for a defined period, particularly suited to roads, water and waste. The project is owned by the private sector for the contract period before it reverts to the public. The projects also attract private sector finance specifically in debt finance discipline to invest in this project. Moreover, it provides greater incentive for private sector contractor in costing and project performance schedule. Model in this output are Build-OperateTransfer (BOT), Build-Own-Operate- Transfer (BOOT), Build-Rent-Own-Transfer (BROT), and Build-Lease-Operate- Transfer (BLOT).

\section{Economic life of the asset or service should be} at least 20 years

The most importance criteria based on PublicPrivate Partnership Unit is the economic life of the asset or service should be at least 20 years. This may guarantee the win-win situation between public sector and private sector.

\section{Projects with outdated technological risk}

As we all know that the technology is continuously emerging. The technology nowadays rapidly changing and very hard for us to followed trending technology. PPP project put criteria that each project must have a lowest technological obsolescence risk. If the risk available, the contracts will state that the operator will update using a new technology based on the project requirement.

4. Project sponsor must be financially strong with a paid up capital of SPV to be at least $10 \%$ of the project value

Financial is the main factor in PPP project because the government offer the project to the private sector in intention to share the risk and financial. PPP project involves partnership with private sector to clearly defined tasks and risks of the project. The main parties would include the SPV created specifically for the project, financiers, construction contractor, facilities management operator, and the public sector which act as procuring authority. All parties must have a strong capital to ensure the project will sustain. SPV is an operator of the project. SPV must have paid up capital at least $10 \%$ of the project value so that they can guaranteed to the government they have that ability to operate and run the project for a long time of period.

\section{POTENTIAL BENEFITS OF PPP}

Malaysian government implement PPP project because it offers several benefits for government and the private sector. After implemented PPP in this country, our economic structure emerging to construction, services, development and agricultural compare previously which had been dominated by agricultural sector, mining and quarrying [12]. However, as the economic increasingly mature and that the country aims to be high income country, services sector contributes $54.5 \%$ to the economic Growth Domestic Product (GDP) [13].These are especially to industries that has strong basis for new growth area like food and beverages, accommodation, retails, finance and insurance.

Besides that, PPP introduce new development areas by improvement of accessibility and mobility such as North South Highway, SMART Tunnel and Government office building in Putrajaya [14]. All of these forms of new townships give benefit the public as it facilitates the movement of passengers and goods. Not only that, the concept of value for money that emphasized in the PPP 
Guidelines also benefit the local economic development where the government had optimized utilization of money even though need to compensate the project after the contracted period of time as long as it guarantees the economic life of an assets is more than 20 years [11].

The PPP support the government in terms of financial and reducing the government expenditure [14] It is because, some of the project financed by the private sector capital itself. It is good for the government itself because the money can be spending on improving the service sector such as education, tourism, health or focus for better protection in military for unpredicted event in future. This has been proven the privatization policy has been a great successful during period 1996 to 2000 which is the total amount of the savings for government capital expenditure are USD16.3billion [15] and RM163.8 billion until 2010 [14]. Moreover, it is really good to avoid debts for a government and have a compensating expenditure for the country.

Furthermore, PPP giving chances to private sectors being innovative in providing solutions towards problems derive from public services. In other words, PPP introduce the private sector technology and innovation in providing better public services through improved operational efficiency for instance Kuala Lumpur Sentral project and Light Rail Transit project. Private sector in creating innovative solutions, which includes better design and management by made specification on the output required and finalize by realizing value of money and increasing the efficiency of public service delivery [16].

PPP gradually exposing state owned enterprises and government to increasing levels of private sector participation (especially foreign) and structuring PPP in a way so as to ensure transfer of skills leading to national champions that can run their own operations professionally and eventually export their competencies by bidding for projects/ joint ventures. Not just that, by application of this PPP, it

Incentives from implementing PPP, will create dynamics in the economy by making Malaysia more competitive in terms of infrastructure facilities. Good infrastructure facilities will not only facilitate local residents but also become a factor in attracting foreign tourists to Malaysia. In addition, the implementation of the PPP helps in enhancing the public sector capability to meet the demand for infrastructure development. Indirectly, the government is able to complete infrastructure facilities faster and save on expenditure. Consequently, PPP had extracting long-term value for money over the life of the project [17].

\section{ISSUES AND RECOMMENDATIONS OF PPP IMPLEMENTATION}

Discussing the PPP issues and recommendation is not an easy endeavor. There are too many issues could be highlight from the PPP implementation and required urgent attention and recommendations for future research. First of all, there a lack of details explanation regarding PPP guidelines. Furthermore, it is crucial for government to have some guidelines in many sector on PPP mode of procurement. Moreover, the guidelines by Public Private Partnership Unit, Prime Minister Department only focus to construction. But as we all know that Malaysia economic boost to servicing sector such as tourism, finance and banking, health and education. Enhancing the servicing sector through PPP may help Malaysia become high income country.

Private sector takes advantages from absence of PPP standard of contracts. and tendering. They will do what it is paid to do and no more than that. Absence of PPP standard of contract shows that the government failure to provide job scope of each stakeholders, failure to give clear policy framework and also hard to define the use of partnership. Private sectors know that the rules of the game are to be respected by the government as rewards of gaining profits. So, they may expect a significant level of control through PPP implementations. Therefore, incentives and performance requirements need to be clearly set out in the contract and tender.

Even though government had form a Public Private Partnership Unit in Prime Minister Department, but still lack of an expertise on the field of project implementation, auditing, legal authority and financing. A special authority committee must be form separately based on PPP needs. The person who suggest, designing and negotiate the project must be different with the person who responsible to evaluate and analyze the potential benefits of PPP implementation. Government should form three stage of committee which the first committee is before project implementation whose help in negosation, designing and planning for the project. Second committee are responsible to monitoring the project schedule in intention to avoid theft, fraud, corruption and over-budget project and the last committee is responsible to evaluate the benefits of the project.

Due to recent circumstance, PPP project research and financial must be more transparency after parliament approval. Details explanation to the people with a relevant benefits of the project may help government gain support from Malaysian and avoid corruption. It also a way to avoid slander and misunderstanding among Malaysian. Project delay due to political debate also must be put under consideration. Brief explanation of the project with a transparency financial expenditure 
helps government to pay more due to project delays and project renegotiation and reconsideration.

PPP project tenders should be published openly. It is because government must try other SPV instead of using same companies, even though the number of capable and experienced SPV is very limited. Moreover, this way can avoid the project being monopolized by company that are familiar with PPP mode of procurement. In addition, it's also a chances for new SPV to take part in PPP implementation.

\section{CONCLUSION}

In order to prove that PPP give beneficial to Malaysian, the commitment and full involvement of the government and private sector must be taken seriously. The government also needs to strengthen the capacity of the organization through the enhancement of the expertise of the officers so that each project is managed with expertise and minimizes the errors that can cause cost loss or delaying the project. Furthermore, effective implementation and monitoring should be done periodically in accordance with the standards so that the project is always supervised by the person responsible for avoiding errors. The Government has the option of implementing a project either through PPP or conventional methods. If a project involves a substantial amount and the allocation of Government development expenditure is limited then the implementation of PPP project development should be considered. Lastly, a review of the strategic plan to determine the effectiveness of the action plan needs to be done to achieve the objectives of the implementation of the Public Private Partnership concept.

\section{REFERENCES}

[1] B. Brans, Analyzing PPPs as a policy tool for Universal Secondary Education in Uganda, Amsterdam: Universiteit Van Amsterdam, 2011.

[2] Robertson, S.L and Verger,A., "Governing Education Through Public Private Partnerships," Centre for Globalisation, Education and Societies, Cheltenham, 2012.

[3] UKAS, "Portal Rasmi Unit Kerjasama Awam Swasta," Unit Kerjasama Awam Swasta, 2015. [Online]. Available: http://www.ukas.gov.my/en/profil-mobile.

[4] UKAS, "Public Private Partnership," in Proceedings Seminar on Public Private Partnership, Kuala Lumpur, 2010.

[5] EPU, "History of Privatization Programme," Jabatan Perdana Menteri, 2006. [Online]. Available:
http://www.epu.jpm.my/New\%20Folder/applic ation\%20and\%20approval/priva.htm.

[6] Government of Malaysia, "Ninth Malaysia Plan,," Putrajaya, 2006.

[7] The star online, "the star online," the star, [Online]. Available: https://www.thestar.com.my /news/nation/2006/07/20/epf-to-provide-bulkof-funding-for-425-projects/. [Accessed 20 July 2006].

[8] Ismail, S. and Khairuddin, A.S, "PRIVATE FINANCE INITIATIVE (PFI) IN MALAYSIA:The need for an issues related to the public sector comparator (PSC)," Journal Akauntasi dan Keuangan Indonesia, vol. 4, no. 2, pp. 137-154, 2007.

[9] EPU, "Tenth Malaysia Plan," The Economic Planning Unit, Prime Minister Department, Kuala Lumpur, 2010.

[10] S. Ismail, "Critical Success factors of public private partnership (PPP) implementatin in Malaysia," Asian Pacific Jpurnal of Business Administration, vol. 5, no. 1, pp. 6-49, 2013.

[11] Public Private Partnership Unit, Public Private Partnership (PPP) Guideline, Putrajaya: Public Private Partnership Unit, Prime Minister Department, 2009.

[12] Kementerian Kewangan Malaysia, "Portal Rasmi Kementerian Kewangan malaysia," [Online]. Available: http://www.treasury.gov.my /index.php/ekonomi/laporan-ekonomi.html. [Accessed 27 Oktober 2017].

[13] Kementerian Kewangan Malaysia, "Laporan ekonomi 2017/2018," Kementerian Kewangan Malaysia, Putrajaya, 2017.

[14] K. A.Rashid, "Public-Private partnership and its significance for Malaysia," CommenwealthGovernance and Growth 2014, no. 2014 edition, pp. 54-57, 2014.

[15] S. Ismail, "Rationales for Public Private Partnership (PPP) Implementation in Malaysia," Journal of Financial management of Property and Construction, vol. 3, no. 19, pp. 188-201, 2014.

[16] Ismail,S. and Harris,F.A, "Challanges in implementing Public Private Partnership (PPP) in Malaysia," in International Conference on Accounting Studies, Kuala Lumpur, 2014.

[17] Sapri M., Hariati A.H., Sheau Ting L. and Sipan I., "Public private partnership benefits in delivering public facilities in Malaysia," in The 4th International Building Control Conference 2016, Kuala Lumpur, 2016. 